\title{
Hot Cocoa:
}

\section{Agricultural Economics and the Ivorian Civil Wars}

\author{
John Biberman \\ Bachelor of Arts, Government \\ Dartmouth College, 2012
}

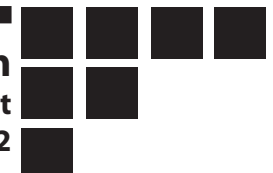

For roughly a decade, Côte d'Ivoire has been bitterly divided by a civil war between its dry Muslim north and its fertile Christian south. Many commentators have attempted to ascribe cultural or social origins to this war, casting it as an example of wider conflict between the Christian and Muslim worlds, while others see it as yet another example of the failings of weak, divided and tribalistic African states. I go beyond these narrow categories to explain the civil war as the natural outcome of a series of rational economic and political choices.

The recent International Criminal Court arraignment of former president Laurent Gbagbo on charges of crimes against humanity marks the culmination of a decade of conflict in Côte d'Ivoire--, one of the most protracted periods of strife in West African history. Following the 1993 death of longtime leader Félix Houphouët-Boigny, or "Le Vieux," the country gradually descended into a largely broken state, divided by two civil wars. The conflict has caused Côte d'Ivoire, whose economic capital Abidjan was once called "the Paris of Africa", to lose its designation as one of Africa's most prosperous countries. Furthermore, the ensuing instability has resulted in the displacement of over a million people.

Côte d'Ivoire's civil war is a complex process, with many disparate causes and ramifications. The main source of conflict has been a series of economic grievances that have fueled the country's political unrest. Economic incentives motivated the government to encourage a rapid expansion of the cocoa crop; however, these policies motivated farmers to harvest their crops beyond a sustainable limit, leading to lower and lower yields while attracting an unsustainable migrant inflow from the north. Faced with building ethnic tensions and the decreasing revenues from this fall in production, the government chose to adopt exclusionary policies towards outsiders thereby increasing ethnic inequality and fracturing the Ivorian national identity. Finally, northern rebels began to fight as ain response to this relative deprivation and the economic opportunity of their own cocoa, which acted as further fuel for the conflict.

I first identify the structural conditions, both natural and political, that led to greater resentments and inequalities between the northern rebels and southern

\section{Côte d'Ivoire civil war is a complex process, with many disparate causes and ramifications.}

government. Then, I analyze the responses to these conditions, and discuss how the outcomes of these interventions increased resentment and inequality due to the perverse economic incentives of an authoritarian state. Finally, I show how elites mobilized their groups as a response to these grievances, using the country's deepening divide as a profit opportunity. All of these factors created a volatile political environment ripe for civil war.

*Your introduction is very light on citations. Please make sure you are including citations for all ideas-even those that are directly 
copied-that aren't your own.

\section{The Economic "Miracle"}

In the twenty years following independence in 1960, Côte d'Ivoire was said to be experiencing an economic "miracle." Exports, especially cocoa, accounted for roughly 40 percent of gross domestic product (GDP) between 1960 and 1981--far more than what neighboring countries experienced. In addition, high commodity prices fueled growth rates as high as 12.3 percent in 1976. ${ }^{1}$ The government used this exceptionally high growth to extract rents from the cocoa sector to fuel industrialization, in a manner similar to other African countries. In 1977, these rents amounted to 16 percent of GDP, or roughly one billion dollars ( or $\$ 2.75$ billion in today's money). ${ }^{2}$ The income from these rents not only helped Côte d'Ivoire advance economically much faster than its neighbors, it also consolidated the Houphouët-Boigny regime's hold on power by providing funds for its patronage mechanism. $^{3}$

Since rents were dependent on the productivity of the agricultural sector, the Ivorian government promoted greater production at a lower cost by inviting cheap labor from abroad to work on cocoa holdings. Known as the Houphouët-Boigny "compromise," this policy guaranteed that land would "belong to those who make it produce," opening the possibility of land ownership for non-citizens. ${ }^{4}$ Drawn by the prospect of having their own fertile lands to work some day, hundreds of thousands of migrant workers streamed across the country's northern borders to take advantage of the opportunity and escape the drought that plagued their own countries. ${ }^{5}$ By 1981 , almost all wage laborers on smallholder farms were immigrants. ${ }^{6}$ Over a million had come in from Upper Volta (present day Burkina Faso) and 500,000 had come to work from Mali. ${ }^{7}$
While this property rights regime succeeded handily in supplying adequate labor to the Ivorian cocoa industry, it had major unforeseen consequences that would reduce future rents and build the foundations for conflict. First, migrant workers who took advantage of the property ownership policy invested in their own smallholder farms when they had earned enough money to do so, often on the land of

\section{New migrant laborers worked on other migrants' farms instead of Ivorian ones}

their former employer. Due to limits on space that could be cultivated, more producers meant a decrease in average production per holding. Increasing economies of scale meant that smaller cocoa farms would lead to a relative fall in total production, and thus a fall in rent potential. ${ }^{8}$ Second, the property rights regime encouraged unlimited expansion and exploitation of the land by treating it as an unlimited, cost-free resource. ${ }^{9}$ Although the policy encouraged higher output at its outset, the free-for-all mentality encouraged by the government hastened a decline in land productivity, a decline in production, and a decline in rent to extract. Falling rents exacerbated the need for greater production and migrant labor, deepening the downward spiral.

The

Houphouët-Boigny compromise improved migrants' welfare and sense of belonging in society, but as land grew scarce, southern ethnic groups began to resent the migrants' success at the expense of the natives. ${ }^{10}$ In the elite Baoulé community, which Houphouët-Boigny had belonged to, migrant laborers had taken so much land from their former holdings that the Baoulé now had trouble turning a profit. New migrant laborers worked on other migrants' farms instead of Ivorian ones. ${ }^{11}$ Having less land reserved for this dominant group also increased pressure on Baoulé politicians, who had less leverage 
to extract rents from foreign ethnic groups. As land became more scarce, the Bété, who mainly earned their livelihood by leasing their fertile land to producers, also began to resent the migrant inflow which had limited access to their own land. ${ }^{12}$ Combined with a worldwide decline in cocoa prices in the 1980 s, overall rents began to fall, forcing the state to adapt austerity policies and extract even more rents. This encouraged greater forest depletion and undermined attempts to diversify the economy. Ultimately, the program was responsible for increased economic hardship at a time when heavy migrant inflow was feeding smoldering resentment. ${ }^{1314}$

\section{Economic Deprivation and Political Exclusion}

Following Houphouët-Boigny's death in 1993, politicians began pursuing an instrumentalist approach, which capitalized on the growing resentment and division in Ivorian society..$^{15}$ In particular, southern politicians seized on the concept of Ivoirité. While Ivoirité was initially invoked to celebrate a common national identity for all Ivorians, the term gradually came to refer to xenophobia of both northern Ivorians and migrant groups by the dominant southern population. Politics based on Ivoirité thus became an ethnic manifestation of growing economic grievances and encouraged a discriminatory system that increased horizontal inequalities.

Economic horizontal inequalities hadalways been problematicin Côted'Ivoire. But as Ivoirité devolved into institutionalized xenophobia, these inequalities were exacerbated, and increased interregional resentment. Northern groups had always been the country's least fortunate peoples. In surveys conducted between 1994 and 1998, northern ethnic groups had the worst literacy and socio-economic prosperity statistics in the country. Five of the six regions with the worst primary school enrollment in 1998 lay in the region generally recognized as the north. ${ }^{16}$ Under Houphouët-Boigny, the government had at least maintained a significant, albeit superficial, positive presence in the region by investing some of the earnings from rents in services and infrastructure for the north. However, as rents decreased and divisions grew, later governments ended this practice, deciding only to invest in the southern half of the country. As a result, the prosperity gap between northern ethnic groups and southerners continued to widen. ${ }^{17}$ Under the pretense of Ivoirité, the government took the opportunity to redesign the country's property rights regime to bar non-citizens from holding land. As both migrants and northerners, suspected of being aliens and already at

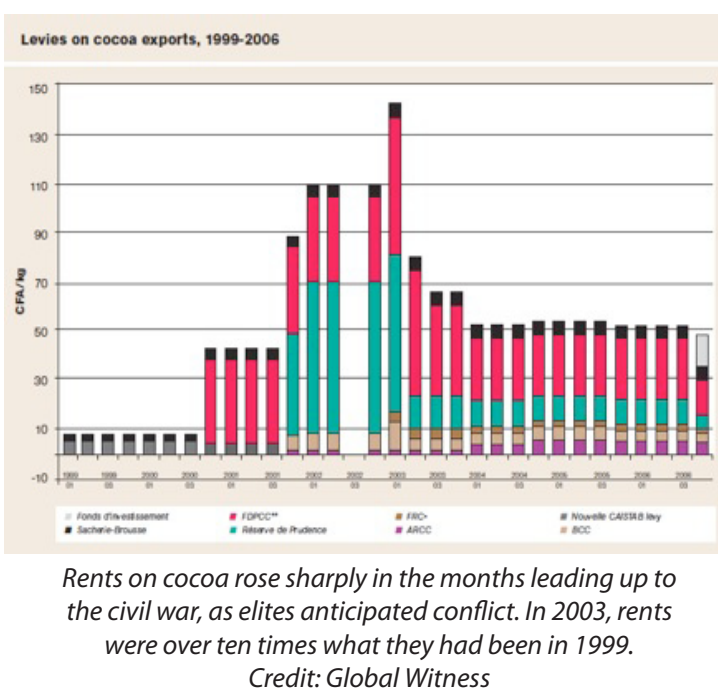

the bottom of the economic pyramid, were evicted from their land, resentment based on these widening horizontal inequalities continued to build. Ethnicity's growing importance made these inequalities more explicit, and contributed to group mobilization.

In government affairs, the concept of Ivoirité was used as an excuse to exclude northern politicians from holding positions of power. This, combined with the resentment from economic horizontal 
inequalities, gave politicians the motivation and fuel to mobilize their constituencies. The Houphouët-Boigny government had taken careful measures to reduce inequality through a system of ethnic quotas. Although the Akan ethnic groups in the south, including the Baoulé, remained the dominant force, no group was excluded from the table. In the 1980 government, the Akan, comprising 42 percent of the general population, comprised only 49 percent of the government and 67 percent of Houphouët-Boigny's inner circle. Likewise, the Voltaics, a northern group representing 18 percent of the population, comprised 14 percent of this government. ${ }^{18}$

Post-Houphouët-Boigny governments were far more instrumental in their approach, markedly over-representing their own groups at the expense of these northerners. In Laurent Gbagbo's 2001 government, the Krou, his own ethnic group, were overrepresented by 225 percent in the government overall and by 358 percent in key positions. The Northern Mandé group of current president Alassane Ouattara was represented only to 43 percent of its size, while Voltaics did not boast a single government minister. Grossly unequal political representation came to a head in 2000, when Ouattara, the country's leading opposition candidate at the time, was barred from running for president on the grounds that he was not a citizen because of the nationality of his parents.

\section{Splitting the Cake in Two}

Their broad economic grievances combined with the political exclusion of their elites endowed northerners with the spirit of rebellion. However, violence in the name of maintaining the power of the elite can engender unintended violent repercussions. ${ }^{19}$ It was thus no surprise when growing violence against Muslims from northern areas resulted in a northern rebellion and a mutiny of northern factions in the army in the early morning of September 19, 2002, sounding the start of the First Ivorian Civil War. The violence could have been contained, had the economic motivations for the rebellion been limited to economic grievances. However, rebellion offered profit opportunities for the elites of both sides more tempting than any peace deal. As one report put it, "many of the main actors profited from the effective partition of the country; political division has meant economic division, and the cake has been split in two." ${ }^{\prime 2}$ In a country whose cocoa crop amounted to 40 percent of world production in 2006, or 1.38 million tons, worth $\$ 1.4$ billion, plenty of money could be siphoned out to fund conflict. Even the relatively dry north grew roughly 3.6 percent of the world crop, worth $\$ 203$ million, easily generating enough money to fight a war while enriching its leaders. ${ }^{21}$

The rebellion, calling itself Les Forces Nouvelles (FN) (or the New Forces) quickly

\section{The violence could have been contained, had the economic motivations for the rebellion been limited to economic grievances}

set up coordinated mechanisms that would extract rents from every accessible point of the cocoa production process. The revenue from these rents would go directly toward financing the war or into the personal coffers of rebellion officials instead of services for the downtrodden population. ${ }^{22}$ These mechanisms became gradually more efficient and institutionalized over time, eventually generating $\$ 30$ million annually between 2004 and $2007 .{ }^{23}$ The FN instituted taxes on its cocoa crop by weight, and forced transporters to pay a "protection tax" to move goods through the country. Forces also blocked cocoa from going south in order to monopolize more export profits. In a striking example of economic competition, the north intentionally maintained lower taxes on cocoa than the 
Abidjan government in order to attract cocoa from the south. ${ }^{24}$ Through these various institutions, the $\mathrm{FN}$ earned more money from cocoa in 2007 than it earned from the infamous "blood diamonds" in its own territory. ${ }^{25}$

If anything, the Gbagbo government's economic manipulations during the war were even more outrageous. In anticipation of future conflict, both the Guëi and Gbagbo governments had created several new institutions to extract more rent from cocoa. Using as many as eight different internal taxes, levies, and registration fees, the domestic rents levied on cocoa production rose from under 15.5 CFA(3 cents) per kilogram in 1999 to 142 CFA (27 cents) per kilogram in March 2003. ${ }^{26}$ Over the same period, export taxes nearly doubled from 120 cfa (23 cents) per kilogram to $220 \mathrm{cfa}$ (40 cents) per kilogram. ${ }^{27}$ Aside from these rents, national cocoa institutions also contributed at least $\$ 20$ million to the war effort, and were shown to have connections with at least one wanted arms dealer. ${ }^{28}$ This is partially because Gbagbo used these institutions to launder money away from the eyes of foreign observers, but it is also because the institution directors appointed by Gbagbo had profited significantly, and had a direct stake in the conflict's outcome. ${ }^{29}$ Finally, similar to the rebels, the national army instituted mandatory "protection fees" of 40,000 CFA (\$75) per truck to escort vehicles to Abidjan. ${ }^{30}$

\section{Changing the Rules of the Game}

Even following the end of the second civil war in 2011, Côte d'Ivoire still appears unstable. The country's long period of turmoil has left it predisposed to political violence, and the divisions remaining within the country could still easily ignite..$^{31}$ But what can be done not only to stop violence of this sort from recurring in Côte d'Ivoire, and what lessons can we glean from this war-torn country to prevent similar outcomes in similar countries in the future? The ICC prosecution of Laurent Gbagbo is a step in the right direction. The stigmatization of such a trial will hopefully discourage such mobilizations in the future. The trial's location outside of the country should also keep Gbagbo, one of the main authors of Ivorian political xenophobia,

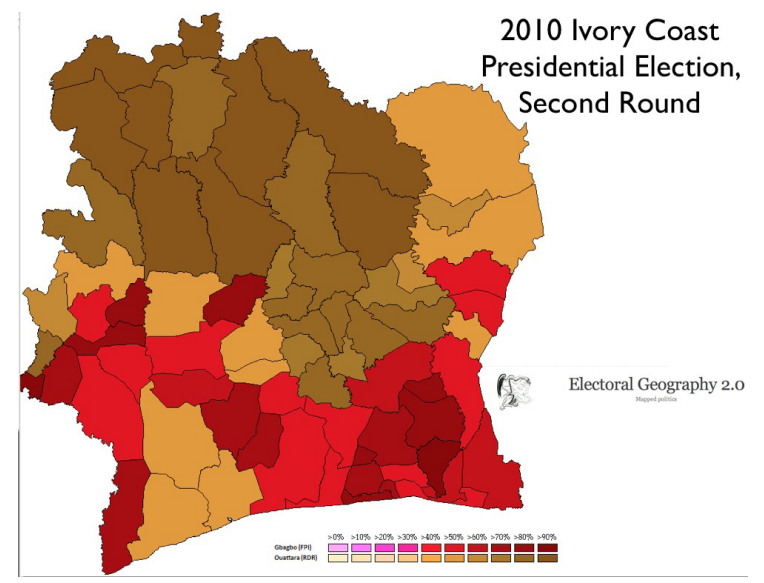

The 2010 Ivorian Presidential Election, which Gbagbo claimed despite having won fewer votes than Ouattara, was particuarily indicative of the continuing divisions within Cote $d^{\prime}$ Ivoire. Note the high overlap between coca production, dominated by southern groups, and the Gbagbo vote.

from becoming a martyr among his supporters. However, if war does indeed ultimately stem from a series of rational choices and legitimate, calculated fears, the most significant steps that can be taken are substantive economic and political reforms. Countries should be more mindful of disparate effects their economic policies, such as investment, have on different demographic and ethnic groups, and how these differences define groups and help them mobilize. Commodity-driven countries should also take further steps to diversify their export economies, reducing their vulnerability to world markets. Finally, national leaders should restrain themselves from consolidating their control around their or any other specific ethnic group, if for no other normative ethical reason than the fear that this political exclusion backfire 
and serve as motivation for other groups to rebel.

The crises in Côte d'Ivoire have served as a textbook model for conflict not only in Sub-Saharan Africa, but also in regions worldwide. Various economic policies created a situation in which agricultural yields fell as a growing migrant population stoked resentment. The ensuing decline in rents motivated elites to exclude other groups from politics and economic benefits, hoping to consolidate power in their own political bases. Instead, this approach backfired disastrously, as repression instead promoted mobilization and the military division of the country. Opportunities for profit within the context of the conflict sustained fighting and gave leaders incentives to continue. Now that the country has finally come to a tentative peace, one must hope that profits fuel the rebuilding of the country instead of providing divisive fodder for its destruction.

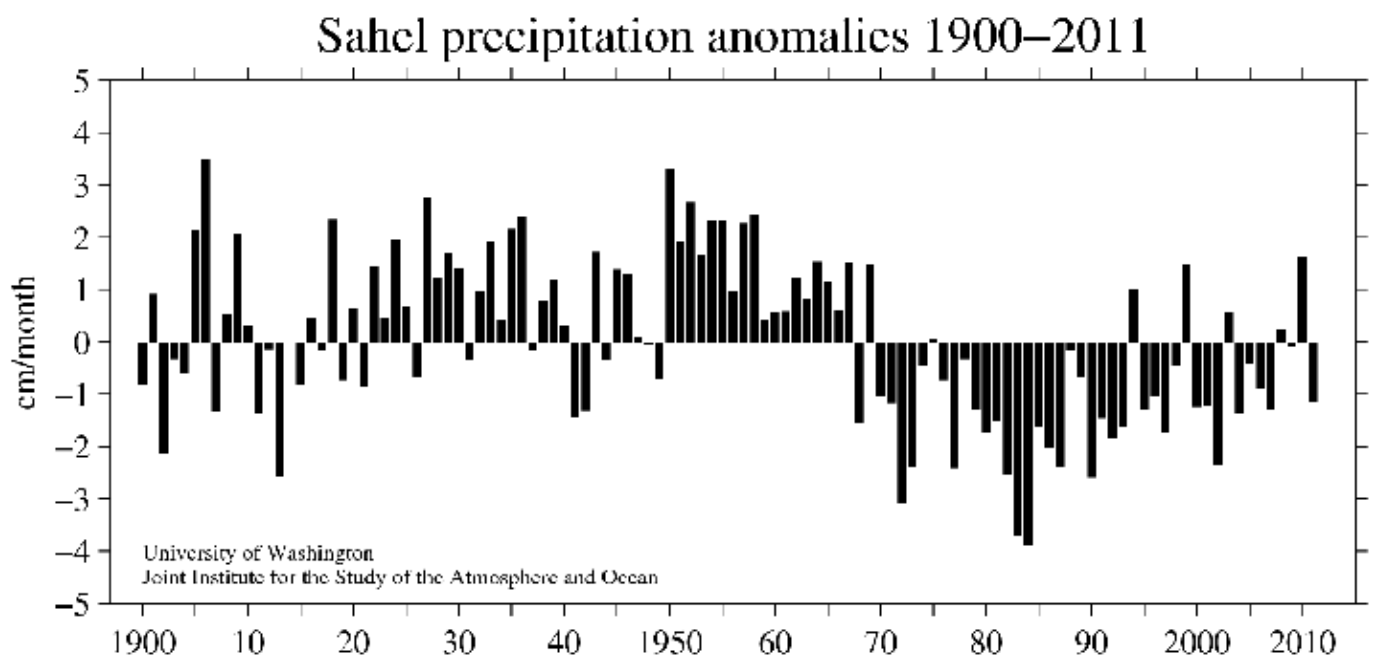

June through October averages over 20-10N, 20W-10E. 1900-2011 climatology

NOAA NCDC Global Historical Climatology Network data

Severe Drought in the Sahel, combined with economic

opportunity in Cote d'Ivoire, attracted millions of

migrants in the decades following independence.

\section{Works Cited}

Africa Research Bulletin. “Blood Chocolate." Economic, Technical and Financial Series 44.5(July 2007): 17404.

Fearon, James and Laitin, David. "Ethnicity, Insurgency and Civil War." American Political Science Review 97.1(February 2003): 75-90.

Global Witness. "Hot Chocolate: How Cocoa Fuelled the Conflict in Côte d'Ivoire." June 2007.

Hecht, Robert. "The Ivory Coast Economic Miracle: What Benefits for Peasant Farmers?" The Journal of Modern African Studies 21.1(March 1983): 25-53.

Langer, Arnim. "Horizontal Inequalities and Violent Group Mobilization in Côte d'Ivoire." Oxford

Studies 33.1 (March 2005): 25-45.

Lewis, Martin W. “Ethnic Dimensions of the Conflict in Côte d'Ivoire." Geocurrents: April 28, 2011.

info/geopolitics/ethnic-dimensions-of-the-conflict-in-ivory-coast

University of Texas Map Collection. "Ivory Coast-Economic Activity, 1973."

cote d'ivoire.html

http://www.lib.utexas.edu/maps/

http://geocurrents 


\section{Endnotes}

1Hecht, Robert. "The Ivory Coast Economic Miracle: What Benefits for Peasant Farmers?" The Journal of Modern African Studies 21.1 (March 1983).

2 lbid.

2 lbid.

3 Woods, Dwayne. "The tragedy of the cocoa pod: rent seeking, land and ethnic conflict in Ivory Coast."The Journal of Modern African

Studies 41.4(2003): 641-55.

4 Langer, Arnim. "Horizontal Inequalities and Violent Group Mobilization in Côte d'Ivoire." Oxford Development Studies 33.1 (March 2005): 25-45.

5 Between 1970 and 1990, countries in the Sahel such as Burkina Faso, Mali and Niger experienced record droughts that helped draw these migrants towards Côte d'Ivoire. See Figure 1.

6 The French had in fact instituted a guest worker program in their colonies in the 1940s. So, this practice was the logical continuation of an economic practice that had already been established(Ibid).

7 Hecht.

8 Hecht.

9 Woods 643.

10 lbid.

11 Woods 650 .

12 Woods 651.

$13 \mathrm{lbid}$.

14 Woods.

15 Multiparty democracy had in fact been instated by the Houphouët-Boigny government following protests over austerity making ethnicity measures. One could thus argue that economic hardship enabled the political structures

16 Langer 36.

17 Ibid 38.

18 Langer 40.

19 Fearon, James and Laitin, David. "Ethnicity, Insurgency and Civil War." American Political Science Review 97.1(February 2003):

20 Global Witness. "Hot Chocolate: How Cocoa Fuelled the Conflict in Côte d'Ivoire." June 2007. 5.

$21 \mathrm{lbid} 34$.

$22 \mathrm{lbid}, 36$

23 lbid 33.

24 lbid, 39

25 Africa Research Bulletin. “Blood Chocolate." Economic, Technical and Financial Series 44.5(July 2007): 17404.

26 See Figure 2.

27 lbid, 21.

28 lbid 24, 29.

$29 \mathrm{lbid} 51$.

30 lbid 39.

31 See Figure 3. 